\title{
Coumarins from the aerial parts of Prangos uloptera (Apiaceae)
}

\author{
Seyed Mehdi Razavi, ${ }^{1}$ Hossein Nazemiyeh, ${ }^{2}$ Rogayeh Hajiboland, ${ }^{1}$ Yashodharan \\ Kumarasamy, ${ }^{3}$ Abbas Delazar, ${ }^{4}$ Lutfun Nahar, ${ }^{5}$ Satyajit D. Sarker $*, 5$ \\ ${ }^{I}$ Department of Plant Sciences, Faculty of Natural Science, Tabriz University, Tabriz, Iran, \\ ${ }^{2}$ Research Center for Pharmaceutical Nanotechnology, Faculty of Pharmacy, Tabriz University of \\ Medical Sciences, Tabriz, Iran, \\ ${ }^{3}$ School of Pharmacy, The Robert Gordon University, Schoolhill, Aberdeen, Scotland, UK, \\ ${ }^{4}$ Faculty of Pharmacy and Drug Applied Research Center, Tabriz University of Medical Sciences, Tabriz, Iran, \\ ${ }^{5}$ School of Biomedical Sciences, University of Ulster, Cromore Road, Coleraine BT52 1SA, Co. Londonderry, \\ Northern Ireland, UK
}

\begin{abstract}
RESUMO: “Cumarinas das partes aéreas de Prangos uloptera (Apiaceae)". Os estudos fitoquímicos das partes aéreas de Prangos uloptera, uma espécie do gênero Prangos endêmica do Irã, forneceram cinco cumarinas, xantotoxina (1), prangenina (2), escopoletina (3), deltoína (4) e prangolarina (5). As estruturas destas cumarinas foram elucidas através de métodos espectroscópicos e o potencial antioxidante de 1-5 foi avaliado pelo ensaio de DPPH. O significado quimiotaxonômico de 1-5 também é discutido.
\end{abstract}

Unitermos: Prangos uloptera, Apiaceae, Umbelliferae, cumarina, furanocumarina, marmesina, antioxidante, quimiotaxonomia.

\begin{abstract}
Phytochemical studies on the aerial parts of Prangos uloptera, an endemic Iranian species of the genus Prangos, yielded five coumarins, xanthotoxin (1), prangenin (2), scopoletin (3), deltoin (4) and prangolarin (5). The structures of these coumarins were elucidated by spectroscopic means, and the antioxidant potential of 1-5 was evaluated by the DPPH assay. The chemotaxonomic significance of $\mathbf{1 - 5}$ is also discussed.
\end{abstract}

Keywords: Prangos uloptera, Apiaceae, Umbelliferae, coumarin, furanocoumarin, marmesin, antioxidant, chemotaxonomy.

\section{INTRODUCTION}

Prangos uloptera DC. (family: Apiaceae alt. Umbelliferae) is an endemic Iranian species of the genus Prangos that comprises ca. 30 species of perennial herbs, distributed in the Mediterranean region, Caucasia, Central Asia, Turkey, Iraq and Iran (Evans, 1989; Mazloomifar et al., 2004; GRIN Databases, 2008). Prangos species, commonly known as 'Djashir' in Iran, are widely used in folk medicine as tonic, and for the treatment of flatulence, haemorrhoids, wounds and leukoplakia (Dokonic et al., 2004; Yasuhiro et al., 2001). Previous phytochemical investigations on the fruits and roots of $P$. uloptera revealed the presence of various coumarins, monoterpenes and sesquiterpenes (Abyshev and Denisenko, 1970, 1973; Sefidkon and Navaii, 2001; Mazloomifar et al., 2004). The essential oils obtained from the umbels of this species have recently been shown to contain various terpenoidal compounds (Nazemieyh et al., 2007). As part of our on-going phytochemical and bioactivity studies on Iranian medicinal plants, we now report on the isolation, identification and antioxidant properties of five coumarins from the aerial parts of $P$. uloptera.

\section{MATERIAL AND METHODS}

\section{General procedures}

UV spectra were obtained in $\mathrm{MeOH}$ using a Hewlett-Packard 8453 UV-Vis spectrometer (Agilent, Germany). Optical rotations were measured on a Bellingham Stanley ADP220 polarimeter. CIMS (Chemical Ionisation Mass Spectrometry) analyses were performed in EPSRC Central Mass Spectroscopy Facility in Swansea, UK, on a Micromass Quattro II triple quadrupole instrument (Waters, UK) in chemical desorption mode using ammonia as CI gas. Mass accuracy was within $0.4 \mathrm{Da}$. CI source temperature was $170{ }^{\circ} \mathrm{C}$ and electron energy was $59 \mathrm{eV}$. NMR spectra were recorded in $\mathrm{CDCl}_{3}$ on a Varian Unity INOVA $400 \mathrm{MHz}$ NMR Spectrometer $400\left(400 \mathrm{MHz}\right.$ for ${ }^{1} \mathrm{H}$ 
and $100 \mathrm{MHz}$ for ${ }^{13} \mathrm{C}$ ) using the residual solvent peaks as internal standard. Chemical shifts $\delta$ were in ppm. The HMBC (Heteronuclear Multiple Bond Coherence) experiment used $\mathrm{J}=9 \mathrm{~Hz}$ and had a $55 \mathrm{~ms}$ long-range coupling delay. A NOESY experiment was carried out with a mixing time of $0.8 \mathrm{~s}$. Spectra were recorded with a probe temperature of $25{ }^{\circ} \mathrm{C}$. 2,2-Diphenyl-1picrylhydrazyl (molecular formula $\mathrm{C}_{18} \mathrm{H}_{12} \mathrm{~N}_{5} \mathrm{O}_{6}, \mathrm{DPPH}$ ) and trolox were purchased from Fluka (UK) and were used without further purification. Precoated aluminium sheets silica gel $60 \mathrm{~F}_{254}(0.25 \mathrm{~mm}$ thickness $)$ TLC plates (Merck, Germany) were used. TLC mobile phases were $n$-hexane-ethylacetate (EtOAc) mixtures of various proportions, e.g. $5 \%$ EtOAc in $n$-hexane, $10 \%$ EtOAc in $n$-hexane, etc. Silica $60 \mathrm{G}$ was used for vacuum liquid chromatography (VLC).

\section{Plant material}

The aerial parts of Prangos uloptera DC., were collected in May 2005, from Mishov-Dagh mountain (altitude $2056 \mathrm{~m}$ ) in the northwest of Iran. A Voucher specimen (No. 1384-1) was deposited in the herbarium of the Department of Plant Sciences, Faculty of Natural Sciences, Tabriz University, Iran, and also in the herbarium of the Plant and Soil Science Department, University of Aberdeen, Scotland (ABD).

\section{Preparation of plant extracts}

The dried and ground aerial parts of P. uloptera $(270$ g) were Soxhlet-extracted, successively, with $n$-hexane, dichloromethane and methanol ( $0.7 \mathrm{~L}$ each). The extracts were concentrated by rotary evaporator at $45{ }^{\circ} \mathrm{C}$.

\section{Isolation and identification of compounds}

The $n$-hexane extract ( $2 \mathrm{~g}$ ) was subjected to vacuum liquid chromatography (VLC) on silica gel, eluting with solvent mixtures of increasing polarity: $100 \% n$-hexane, $n$-hexane-EtOAc, $100 \%$ EtOAc and $100 \% \mathrm{MeOH}$, to yield a number of fractions which upon initial thin layer chromatographic (TLC) analyses were grouped into 16 main fractions. Fractions 14-16 (80-100\% EtOAc in $n$-hexane and $100 \% \mathrm{MeOH})$ were further analysed by preparative TLC (mobile phase acetone: $\left.\mathrm{CHCl}_{3}=5: 95\right)$ to afford five coumarins, xanthotoxin $\left(1,10.1 \mathrm{mg}, \mathrm{R}_{\mathrm{f}}=0.5\right)$, prangenin (heraclenin, 2, $\left.9.3 \mathrm{mg}, \mathrm{R}_{\mathrm{f}}=0.55\right)$, 6-methoxy-7-hydroxycoumarin (scopoletin, 3, $13.0 \mathrm{mg}, \mathrm{R}_{\mathrm{f}}=0.43$ ), marmesin angelate (deltoin, $4, \mathrm{R}_{\mathrm{f}}=0.64,10.2 \mathrm{mg}$ ) and marmesin isovalerate (oxypeucedanin or prangolarin, 5, $9.2 \mathrm{mg}, \mathrm{R}_{\mathrm{f}}=0.60$ ). The structures of the isolated compounds 1-5 were elucidated by direct comparison of their UV, specific rotation (where applicable), ESIMS, ${ }^{1} \mathrm{H}$ and ${ }^{13} \mathrm{C}$ NMR data with published data, and by comprehensive $1 \mathrm{D}$ and
2D NMR analyses.

\section{Antioxidant assay}

2,2-Diphenyl-1-picrylhydrazyl (DPPH), molecular formula $\mathrm{C}_{18} \mathrm{H}_{12} \mathrm{~N}_{5} \mathrm{O}_{6}$, was obtained from Fluka Chemie AG, Bucks. Trolox ${ }^{\circledR}$ (6-hydroxy-2,5,7,8tetramethylchroman-2-carboxylic acid) was obtained from Sigma-Aldrich, UK (http://www.sigmaaldrich. com/Area_of_Interest/Europe_Home/UK.html). The method used by Takao et al. (1994) was adopted with suitable modifications (Kumarasamy et al., 2007). DPPH $(8 \mathrm{mg})$ was dissolved in $\mathrm{MeOH}(100 \mathrm{~mL})$ to obtain a concentration of $80 \mu \mathrm{g} / \mathrm{mL}$.

Qualitative Analysis: Test samples were applied on a Silica gel TLC plate and sprayed with DPPH solution using an atomiser. It was allowed to develop for $30 \mathrm{~min}$. The colour changes (purple on white) were noted.

Quantitative Analysis: Serial dilutions were carried out with the stock solutions $(1 \mathrm{mg} / \mathrm{mL})$ of the compounds (1-5) to obtain concentrations of $5 \times 10^{-1}, 5$ x $10^{-2}, 5 \times 10^{-3}, 5 \times 10^{-4}, 5 \times 10^{-5}, 5 \times 10^{-6} \mathrm{mg} / \mathrm{mL}$. Diluted solutions ( $2 \mathrm{~mL}$ each) were mixed with DPPH $(2 \mathrm{~mL})$ and allowed to stand for $30 \mathrm{~min}$ for any reaction to occur. The UV absorbance was recorded at $517 \mathrm{~nm}$. The<smiles>COc1c2occc2cc2ccc(=O)oc12</smiles>

1<smiles>C[C@@H](Oc1c2ccoc2cc2oc(=O)ccc12)[C@@]1(C)O[C@@H]1C</smiles>
2<smiles>COc1cc2ccc(=O)oc2cc1O</smiles>
3<smiles>[R]C(C)(C)[C@@H]1[CH]c2cc3ccc(=O)oc3cc2O1</smiles>

$4 \mathrm{R}=-\mathrm{COC}\left(\mathrm{CH}_{3}\right)=\mathrm{CHCH}_{3}$ $5 \mathrm{R}=-\mathrm{COCH}_{2} \mathrm{CH}\left(\mathrm{CH}_{3}\right)_{2}$ 
Table 1. ${ }^{1} \mathrm{H}$ (coupling constant $J$ in $\mathrm{Hz}$ in parentheses) coumarins 1-5.

\begin{tabular}{|c|c|c|c|c|c|}
\hline \multirow[t]{2}{*}{ Position } & \multicolumn{5}{|c|}{ Chemical shift $(\delta)$ in ppm } \\
\hline & 1 & 2 & 3 & 4 & 5 \\
\hline 3 & $6.40 \mathrm{~d}(9.5)$ & $6.32 \mathrm{~d}(9.8)$ & $6.25 \mathrm{~d}(9.5)$ & $6.24 \mathrm{~d}(9.5)$ & $6.24 \mathrm{~d}(9.5)$ \\
\hline 4 & $7.78 \mathrm{~d}(9.5)$ & $8.24 \mathrm{~d}(9.8)$ & $7.65 \mathrm{~d}(9.5)$ & $7.60 \mathrm{~d}(9.5)$ & $7.60 \mathrm{~d}(9.5)$ \\
\hline 5 & $7.42 \mathrm{~s}$ & - & $7.44 \mathrm{~s}$ & $7.24 \mathrm{~s}$ & $7.24 \mathrm{~s}$ \\
\hline 6-OMe & - & - & $3.94 \mathrm{~s}$ & - & - \\
\hline 8 & - & $7.19 \mathrm{~d}(0.5)$ & $6.84 \mathrm{~s}$ & $6.67 \mathrm{~s}$ & $6.67 \mathrm{~s}$ \\
\hline 8-OMe & $4.30 \mathrm{~s}$ & - & - & - & - \\
\hline 2 ' & $7.68 \mathrm{~d}(2.2)$ & $7.63 \mathrm{~d}(2.3)$ & - & $5.00 \mathrm{t}(8.6)$ & $4.98 \mathrm{t}(8.6)$ \\
\hline \multirow[t]{2}{*}{$3{ }^{\prime}$} & $6.82 \mathrm{~d}(2.2)$ & $6.98 \mathrm{~d}(2.3)$ & - & $3.18 \mathrm{dd}(15.8,8.6)$ & $3.14 \mathrm{dd}(15.8,8.6)$ \\
\hline & & & & $3.28 \mathrm{dd}(15.8,8.6)$ & $3.20 \mathrm{dd}(15.8,8.6)$ \\
\hline \multirow[t]{2}{*}{$4^{\prime}-2 \times \mathrm{Me}$} & - & - & - & $1.50 \mathrm{~s}$ & $1.49 \mathrm{~s}$ \\
\hline & & & & $1.60 \mathrm{~s}$ & $1.59 \mathrm{~s}$ \\
\hline \multirow[t]{2}{*}{1 ', } & - & $4.66 \mathrm{dd}(6.4,4.4)$ & - & - & - \\
\hline & & $4.46 \mathrm{dd}(6.4,4.4)$ & & & \\
\hline $2 "$, & - & $3.25 \mathrm{~d}(4.4)$ & - & - & $2.05 \mathrm{~d}(7.6)$ \\
\hline 2'"-Me & - & - & - & $1.60 \mathrm{~s}$ & - \\
\hline 3, & - & - & - & $6.46 \mathrm{q}(6.4,13.2)$ & $1.90 \mathrm{~m}$ \\
\hline 3'"-Me & - & - & - & $1.56 \mathrm{~d}(6.4)$ & - \\
\hline $3 " '-2 \times \mathrm{Me}$ & - & $1.36 \mathrm{~s}$ and $1.43 \mathrm{~s}$ & - & - & $0.80 \mathrm{~d}(6.6)$ and $0.80 \mathrm{~d}(6.6)$ \\
\hline
\end{tabular}

Table 2. ${ }^{13} \mathrm{C}$ NMR data of coumarins $1-5$.

\begin{tabular}{|c|c|c|c|c|c|}
\hline \multirow[t]{2}{*}{ Position } & \multicolumn{5}{|c|}{ Chemical shift $(\delta)$ in ppm } \\
\hline & 1 & 2 & 3 & 4 & 5 \\
\hline 2 & 161.0 & 162.4 & 160.9 & 161.4 & 161.3 \\
\hline 3 & 114.7 & 113.6 & 112.5 & 112.7 & 112.6 \\
\hline 4 & 144.4 & 144.9 & 144.3 & 143.6 & 143.6 \\
\hline 5 & 113.0 & 149.0 & 110.5 & 123.2 & 123.2 \\
\hline 6 & 126.3 & 114.6 & 146.5 & 124.6 & 124.6 \\
\hline 6-OMe & - & - & 58.7 & - & - \\
\hline 7 & 147.9 & 158.5 & 148.4 & 163.5 & 163.2 \\
\hline 8 & 132.7 & 95.3 & 102.3 & 97.9 & 97.9 \\
\hline 9 & 143.8 & 152.9 & 148.6 & 155.8 & 155.8 \\
\hline 10 & 116.5 & 107.9 & 110.8 & 112.7 & 112.7 \\
\hline 8-OMe & 61.0 & - & - & & \\
\hline $2^{\prime}$ & 146.7 & 139.4 & - & 88.9 & 88.7 \\
\hline $3^{\prime}$ & 107.2 & 104.9 & - & 29.6 & 29.7 \\
\hline 4 ' & - & - & - & 81.9 & 8.9 \\
\hline \multirow[t]{2}{*}{$4^{\prime}-2 \times \mathrm{Me}$} & - & - & - & 22.1 & 21.9 \\
\hline & & & & 21.3 & 21.1 \\
\hline 1, & - & - & 60.0 & 167.3 & 172.3 \\
\hline 2, & - & - & 61.5 & 129.4 & 44.5 \\
\hline 2'"-Me & - & - & - & 11.8 & 25.8 \\
\hline 3, & - & & 72.8 & 137.1 & - \\
\hline 3"'-Me & - & - & - & 14.3 & - \\
\hline \multirow[t]{2}{*}{$3 ",-2 \times M e$} & & & 25.0 & - & 22.3 \\
\hline & & & 19.4 & & \\
\hline
\end{tabular}

experiment was performed in duplicate and the average absorption was noted for each concentration. The same procedure was followed for the positive control Trolox ${ }^{\circledR}$. The $\mathrm{RC}_{50}$ value, which is the concentration of the test material that reduces $50 \%$ of the free radical concentration, was calculated as $\mathrm{mg} / \mathrm{mL}$.

\section{RESULTS AND DISCUSSION}

Chromatographic analyses of the $n$-hexane extract of the aerial parts of P. uloptera afforded two furanocoumarins, xanthotoxin (1, Masuda et al., 1998) and prangenin (2, Miftakhova et al., 2001), two dihydrofuranocoumarins, deltoin (4, Baba et al., 1989) and prangolarin (5, Kapoor et al., 1972; Wei and Ito, 2006), and a simple coumarin, scopoletin (3, SDBS Database, 2008). The structures of the isolated coumarins (1-5) were elucidated by direct comparison of 
Table 3. Antioxidant activity of the coumarins (1-5) isolated from P. uloptera.

\begin{tabular}{cc}
\hline Compounds/Extracts & $\begin{array}{c}\text { The DPPH assay } \\
\left(\mathrm{RC}_{50} \text { in } \mathrm{mg} / \mathrm{mL}\right)\end{array}$ \\
\hline $\mathbf{1}$ & $>1.00$ \\
$\mathbf{2}$ & $>1.00$ \\
$\mathbf{3}$ & $2.43 \times 10^{-2}$ \\
$\mathbf{4}$ & $3.98 \times 10^{-1}$ \\
$\mathbf{5}$ & $3.87 \times 10^{-1}$ \\
Trolox & $2.60 \times 10^{-3}$ \\
\hline
\end{tabular}

their respective UV, specific rotation (where applicable), CIMS, ${ }^{1} \mathrm{H}$ and ${ }^{13} \mathrm{C}$ NMR data with published data, and by comprehensive $1 \mathrm{D}$ and $2 \mathrm{D}$ NMR analyses. The unambiguous assignment of all ${ }^{1} \mathrm{H}$ and ${ }^{13} \mathrm{C}$ NMR signals for these compounds has been presented in Tables 1 and 2 .

Although coumarins have previously been reported from the roots and fruits of P. uloptera, to our knowledge, this is the first report on the occurrence of coumarins in the aerial parts of this plant. Also, except xanthotoxin (1) and prangenin (2), none of these coumarins (3-5) have ever been reported from this plant. Xanthotoxin (1) and scopoletin (3) occur in many genera of the family Apiaceae as well as other families, e.g. Rutaceae. The genus Prangos is well-known for producing simple and furanocoumarins with various degrees of oxygenation and prenylations (ISI Database, 2008). Within the genus Prangos, prangenin (2) occurs in a number of species, including $P$. equisetoides (Kuznetsova et al., 1979), P. fedtschenkoii, P. ferulaceae, P. hissarica (Combined Chemical Dictionary, 2008; ISI Database, 2008), P. lamellate (Donchul et al., 1979), P. pabularia (Sood et al., 1978; Tada et al., 2002), $P$. sarawschanica (Combined Chemical Dictionary, 2008) and P. uloptera (Abyshev and Denisenko, 1973). However, apart from the genus Prangos, prangenin (2) has also been reported from a few other genera, e.g. Atalantia, Chlamydomonas, Citrus, Eriostemon, Halocnemum, Heracleum, Phebalium and Stauranthus, (ISI Database, 2008; Combined Chemical Dictionary, 2008). The occurrence of deltoin (4) within the genus Prangos is rather restricted mainly to P. uloptera and P. fedtschenkoi, but it has been isolated from a few other genera, e.g. Peucedanum, Saposhnikovia, Seseli and Zosima. Marmesin isovalerate (prangolarin or oxypeucedanin, 5) occurs widely in the family Apiaceae, and also in the genera Atalantia, Citrus and Poncirus of the family Rutaceae (Combined Chemical Dictionary, 2008).

The antioxidant potential of 1-5 was evaluated by the DPPH assay (Kumarasamy et al., 2007). In the qualitative DPPH assay, except 3, all compounds showed extremely low levels of antioxidant activity by displaying faint white spots against a purple background on the TLC plates. In the quantitative DPPH assay, scopoletin (3) was the most active among all compounds, and displayed a significant antioxidant activity with a
$\mathrm{RC}_{50}$ value of $2.43 \times 10^{-2}$ (Table 3 ).

\section{REFERENCES}

Abyshev AZ, Denisenko PP 1970. Coumarins and furocoumarins from fruits of Prangos uloptera. Khim Prir Soedin (6): 758.

Abyshev AZ, Denisenko PP 1973. Coumarins composition of Prangos uloptera roots. Khim Prir Soedin (1): 767.

Baba K, Yoneda Y, Kozawa M, Fujita E, Wang NH, Yuan CQ 1989. Studies on Chinese traditional 1 medicine 'Fang-Feng' (II). Comparison of several FangFeng by coumarins, chromones and polyacetylenes. Shoyakugaku Zasshi 43: 216-221.

Combined Chemical Dictionary 2008. Chapman \& Hall/CRC Press LLC, USA. Available on-line at: http://www. chemnetbase.com/

Dokoric D, Bulatoric VM, Bozic BD, Kataronovski MV, Zrakie TM, Kovacenic N 2004. 3,5-Nonadiyne isolated from the rhizome of Cachrys ferulaceae inhibits endogenous nitric oxide release by rat peritoneal macrophages. Chem Pharm Bull 52: 853-854.

Donchul TYU, Kuznetsova GA, Sokolova EA, Kuzmina LV 1979. Coumarins from the roots of Prangos lamellate. Khim Prir Soedin (6): 849-850.

Evans WC 1989. Trease and Evan's Pharmacognosy, $13^{\text {th }}$ edn. Bailliere Tindall, London.

GRIN Database 2008. USDA, ARS, National Genetic Resources Program, Germplasm Resources Information Network (GRIN) online database, National Germsplasm Resources Laboratory, Beltsville, Maryland. Available on-line at: http:// www.ars-grin.gov/cgi-bin/npgs/html/taxon. pl?29559.

ISI Database 2008. ISI Web of Knowledge Service for UK Education, supported by MIMAS at The University of Manchester and hosted by Thomson Scientific. Available on-line at: http://portal.isiknowledge.com/ portal.cgi?DestApp=WOS\&Func $=$ Frame.

Kapoor SK, Zaman A, Sharma YN 1972. Extractives of Angelica glauca. Phytochemistry 11: 475.

Kumarasamy Y, Byres M, Cox PJ, Jaspars M, Nahar L, Sarker SD 2007. Screening seeds of some Scottish plants for free-radical scavenging activity. Phytother Res 21: 615-621.

Kuznetsova GA, Danchul TYU, Medvedev VN, Sokolova EA, Kuzmina LV 1979. Coumarins of the roots undergrounds and fruits of Prangos equisetoides. Khim Prir Soedin (6): 850.

Masuda T, Takasugi M, Anetaki 1998. Psoralen and other linear furanocoumarins as phytoalexins in Glehnia littoralis. Phytochemistry 47: 13-16.

Mazloomifar H, Bigdeli M, Saber M, Rustaiyan A 2004. Essential oil of Prangos uloptera DC. from Iran. $J$ Essent Oil Res 16: 415-416.

Miftakhova AF, Burasheva GS, Abilov ZA, Ahmad VU, 
Zahid M 2001. Coumarins from the aerial part of Halocnemum strobilaceum. Fitoterapia 72: 319-321.

Nazemiyeh H, Razavi SM, Delazar A, Hajiboland R, Mozaffarian V, Nahar L, Sarker SD 2007. Essential oil composition of the umbels and fruits of Prangos uloptera DC. Nat Prod Commun 2: 91-93.

SDBS Database 2008. Spectral Database for Organic Compounds, National Institute of Advanced Industrial Science and Technology (AIST), Japan. Available on-line at: http://www.aist.go.jp/RIODB/ SDBS/cgi-bin/cre_index.cgi.

Sefidkon F, Navaii MN 2001. Chemical composition of the oil of Prangos uloptera DC. J Essent Oil Res 13: 84-85.

Sood S, Gupta BD, Banerjee SK, Rao PR 1978. Coumarins from umbels of Prangos pabularia Lind,. J Indian Chem Soc 55: 850-851.

Tada Y, Shikishima Y, Takaishi Y, Shibata H, Higuti H, Honda G, Ito M, Takeda Y, Kodzimatov L, Ashurmatov O, Ohmoto Y 2002. Coumarins and gamma-pyrone derivatives from Prangos pabularia: antibacterial activity and inhibition of cytokine release. Phytochemistry 59: 649-654.

Takao T, Watanabe N, Yagi I, Sakata K 1994. A simple screening method for antioxidants and isolation of several antioxidants produced by marine bacteria from fish and shellfish. Biosci Biotech Bioch 58: 1780-1783.

Wei Y, Ito Y 2006. Preparative isolation of imperatorin, oxypeucedanin and isoimperatorin from traditional Chinese herb "bai zhi" Angelica dahurica (Fisch ex Hoffm) Benth. et Hook using multidimensional highspeed counter-current chromatography. JChromatogr A 1115: 112-117.

Yasuhiro S, Yoshishima T, Gisho H, Michiho I, Yoshio T, Olimjon K, Kodzimator O, Ashurmator O 2001. Terpenoids and gamma pyrone derivatives from Prangos teshiganica. Phytochemistry 57: 135-141. 